Chapter 4

\title{
Microbial Quality of Medicinal Plant Materials
}

\author{
Marcelo Gonzaga de Freitas Araújo and \\ Taís Maria Bauab \\ Additional information is available at the end of the chapter \\ http://dx.doi.org/10.5772/51072
}

\section{Introduction}

The use of medicinal plants is continually expanding worldwide. The increasing search for therapeutic agents derived from plant species is justified by the emergence of diseases, yet without proper treatment, and the growth of scientific knowledge about the herbal medicines as important treatment alternatives. Therefore, the quality and safety of herbal preparations are also of great concern [1]. The reference [2] explained that quality is the basis of reproducible efficacy and safety of herbal drugs, and to ensure the standard of research on herbal medicines, the quality of the plant materials or preparations is of utmost importance. With the ever increasing use of herbal medicines and the global expansion of the herbal medicines market, safety has become a concern for both health authorities and the public in many countries. This is because many contaminants and residues that may cause harm to the consumers have been reported [3].

The microbial load of plants is the result of a series of influences (Figure 1). By their origin, herbal drugs are subject to contamination by microorganisms from soil, air and water may be present potentially pathogenic microorganisms to man. Microbial contamination of medicinal herbal can be influenced by environmental factors such as temperature, humidity and extent of rainfall during pre-harvesting and post-harvesting periods, handling practices and the storage conditions of crude and processed medicinal-plant materials. In order to improve the purity and safety of the products, observation of basic hygiene during preparation, standardization of some physical characteristic such as moisture content, $\mathrm{pH}$ and microbiological contamination levels are desirable $[1,4,5]$.

The presence of microbial contaminant in non sterile pharmaceutical products can reduce or even inactivate the therapeutic activity of the products and has the potential to adversely affect patients taking the medicines. As herbal medicinal products are complex mixtures 
which originate from biological sources, great efforts are necessary to guarantee a constant and adequate quality. Manipulation and processing factors largely determine the microbiological quality of the final products [6]. Previous studies have confirmed the presence of potential contaminants in herbal preparations [7-10]. Thus, manufacturers should ensure the lowest possible level of microorganisms in the raw material, finished dosage forms and the packaging components to maintain appropriate quality, safety and efficacy of the natural products [9].

This review intends to contribute to knowledge regarding the microbial contamination of medicinal plants by considering the influence of different commonly used pharmaceutical preparation techniques on the microbiological status of the products. Finally, quality standards will be discussed, considering the main guidelines of microbial quality control and through quality assurance measures such as good manufacturing practices (GMP) for herbal medicines.

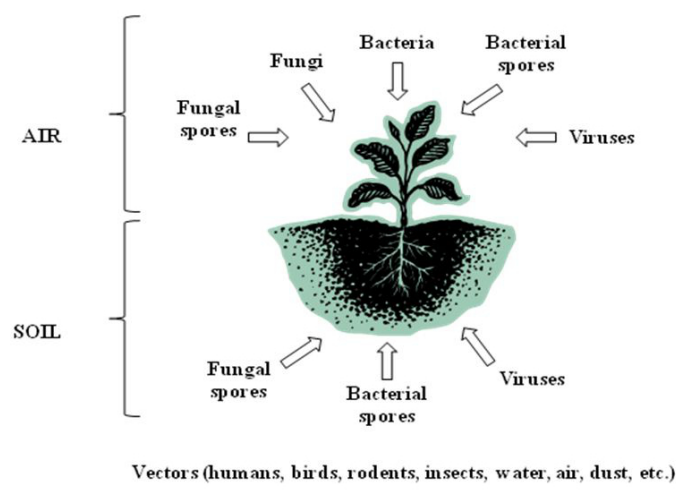

Figure 1. Influence of environmental factors and possible pathways of microbial contamination of medicinal herbs (adapted from [4]).

\section{Common microbial contaminants associated with medicinal plants}

The growing, harvesting and manipulation methods usually applied cannot avoid microbial contamination of the plant material which therefore reflects the environmental conditions as well as the specific hygiene during the diverse treatments [4]. Biological contamination refers to impurities in medicinal herbs and their preparations and products, and may involve living microbes such as bacteria and their spores, yeasts and moulds, viruses, protozoa, insects (their eggs and larvae), and other organisms. However, products of microbial metabolism such as toxic, low-molecular-weight metabolites from moulds are important chemical 
contaminants [11]. The main microbial contamination of plant materials, in general, are attributed to total aerobic mesophilic, enterobacterial, yeast and mould [4].

The presence of higher numbers of spores bacteria could be explained by the fact that some of these organisms (e.g. Bacillus and Clostridium spp.) produce spores which are resistant to harsh processing, elevated heat and dry conditions. Therefore, they can survive for a long time on the product in a dormant state. Bacillus cereus and Clostridium perfringens are recognized as having potential pathogenicity and have been incriminated in food poisoning [12]. Although bacterial endospores and fungal spores can be regarded as the two dominating groups of contaminants associated with medicinal plants, a broad diversity of bacterial, fungal cells and viruses can be found either in or on the plant material [4]. B. cereus and C. perfrigens were isolated from chamomile and other herbs by [13].

Although enterobacteria can be found in nature, this family possesses some indicative value towards faecal contamination. The presence of enterobacteria and E. coli reflect the situation regarding faecal contamination [7]. Together with the group of coliforms, it can be taken as an indicator for undesirable hygiene conditions, although this conclusion has to be related to the magnitude of viable count measured [4]. Staphylococcus aureus is not common contaminant of this type of plant material and relatively rarely found. However, contamination could provide amount of enterotoxin produced by S. aureus, depending on the specific nature of the individual [11].

Herbal medications are likely to be contaminated with a wide variety of others potentially pathogenic bacteria. In a study whose was evaluated the bacterial contamination of powdered herbal medicinal preparations sourced from identified herbal retail outlets in different parts of Kaduna, Nigeria, the results showed that a number of herbal remedies were contaminated with Salmonella typhi and Shigella spp., besides E. coli and S. aureus [1]. In addiction, the presence of pathogenic bacteria like B. cereus, Aeromonas hydrophila, Shigella spp., Enterobacter agglomerans, E. cloacae, Vibrio fluvialis, Pasteurella multocida, S. epidermidis, Acinetobacter iwoffii, Klebsiella spp., B. subtilis and Pseudomonas aeruginosa, and fungi Rhizopus stolonifer also were observed to be present in plant samples analyzed recently [14,15].

Because they are widespread in the atmosphere, moulds are common natural contaminants of medicinal herbs. It is known that, under favourable conditions, some fungi can synthesize toxical metabolites - mycotoxins. Among the known mycotoxins, the most toxic one is aflatoxin synthesised by species of $A$. flavus and A. parasiticus, and a minor number of other fungi [10]. Contamination by $A$. flavus, the most famous aflatoxin producer, is common in medicinal plant and herbal tea [16]. A. flavus colonization does not necessarily reduce yield, but causes economic losses by contaminating with aflatoxin [17]. In a study of 91 medicinal herb samples in Brazil [18], were found that $50 \%$ of aerial part samples were contaminated with fungi. Samples of medicinal plants were evaluated by [5] for the fungal contamination, and results indicated that predominant mycoflora ( $89.9 \%$ of the isolates) corresponded to genera Aspergillus and Penicillium, which are extremely important from the mycotoxicological standpoint. The fungal contamination of powdered herbal medicinal preparations sourced from some herbal retail outlets in some parts of Nigeria was evaluated by [19] and 
the results showed that all of the herbal preparations had the presence of fungal contaminants with predominance of Aspergillus spp. and Penicillium spp., but Mucor spp., Candida spp., Trichosporium spp., also were found. The fungal deterioration adversely affects the chemical composition of the raw materials and thereby decreases the medicinal potency of herbal drugs [20].

The risk of the presence of microorganisms in a plant product depends on this finality of the use, its nature and its potential damage that may be caused to the consumers. Considering natural flora, current production conditions and the need to warrant the quality and the safety of these products, monographs establish a maximum fungal contamination limit for products that contain raw material of natural origin [5]. Although high fungal loads may be accepted due to the natural origin of those products, they indicate the potential for spoilage and mycotoxigenesis.

\section{Influence of different preparation techniques on the microbiological quality}

The production of an herbal medicine generally involves the steps in which a vegetable is subjected to unfavorable conditions to survival of microorganisms. Next, we introduce some of these processes and their influence on the microbial load.

\subsection{Drying process}

Drying is basically defined as the decreasing of plant moisture content, aimed at preventing enzymatic and microbial activity, and consequently preserving the product for extend shelf life [21]. Drying is the most common and fundamental method for post-harvest preservation of medicinal plants because it allows for the quick conservation of the medicinal qualities of the plant material in an uncomplicated manner. This process may also contribute to facilitate the marketing of plants, because drying results in reduction of the weight and volume of the plant with positive consequences for transport and storage [21,22].

The optimization of the drying process contributes to physical, chemical and microbiological stability of the medicinal herbs. The choice of drying conditions depend on the moisture content of tissue at harvest, the plant parts used, and the temperature best suited for preservation of the requested ingredients. For this reason, adequate dryers are needed, using temperature, velocity and humidity values for drying air that provides a rapid reduction in the moisture content without affecting the quality of the active ingredients of medicinal plants [21].

Medicinal plants can be dried in a number of ways: in the open air (shaded from direct sunlight); placed in thin layers on drying frames, wire-screened rooms or buildings; by direct sunlight, if appropriate; in drying ovens/rooms and solar dryers; by indirect fire; baking; 
lyophilization; microwave; or infrared devices. When possible, temperature and humidity should be controlled to avoid damage to the active chemical constituents. In the case of natural drying in the open air, efforts should be made to achieve uniform drying of medicinal plant materials and so avoid mould formation [23].

Spray drying technique has been widely used to obtain dried extracts presenting better technological characteristics and greater concentration of biological active constituents. This method is widely used in the pharmaceutical industry, despite the high temperature drying $\left(100^{\circ} \mathrm{C}\right.$ to $\left.200^{\circ} \mathrm{C}\right)$, the contact time between the material to be dry and hot air is extremely fast, less than 1 minute, theoretically is not enough to remove the microorganisms [24]. Comparative microbiological analysis of drug pulverized, extraction in liquid phase and the the spray drying extraction, using Phyllanthus niruri L., revealed that there is a significant reduction in microbial load, caused by the extraction in liquid process, while the spray dryer, despite the high temperature, did not affect the microbial load [25].

Drying at high temperature decreases the total aerobic microbial count in herbs. Water is a significant component of biological materials. Drying methods can lower the water activity to the level required for preventing growth of Aspergillus species and also for ensuring quality of medicinal herbs which may get destroyed upon over drying [10]. Exposure of herbs to microwaves and warm-air ovens can be efficient to reduce the microbial load, but they are not recommend to medicinal herbs containing volatile oils. The reference [26] evaluated both method of drying of plant, and reduction the microbial load present on the plants was observed but the effect on the volatile oil profile was profound by microwave drying, and warm drying air revealed that at temperatures $>60^{\circ} \mathrm{C}$, most of the volatile constituents were lost.

Other methods such as freeze-drying, oven drying and tray drying have been previously used to preserve medicinal herbs but to date there is little information in the literature on the effect of these drying conditions on the decrease of microbial loads [27].

Once drying is complete, plants are packaged in preparation for shipping or other further processing.

\subsection{Extraction methods}

Water is almost universally the solvent used to extract activity. At home, dried plants can be ingested as teas (plants steeped in hot water) or, rarely, tinctures (plants in alcoholic solutions) or inhaled via steam from boiling suspensions of the parts. Dried plant parts can be added to oils or petroleum jelly and applied externally. Poultices can also be made from concentrated teas or tinctures [28]. These kinds of preparations are usually called medicinal teas and are prepared using natural plants collected, dried and packaged without an effective hygienic and sanitary control. In addition, there can be microbiological contamination and controlling microbial contamination can be difficult in aqueous extracts [13]. 
Environmental dust settled on different parts of the plant and other contaminations can carry very significant amounts of bacterial and moulds spores [13]. However, those drugs which are subjected to cold water extraction (herbal maceration) may host a considerable amount of microbes, and the extraction procedure carried out at ambient temperature usually enables microbial multiplication [4]. The application of hot water extraction usually compensates for microbiological contaminations, since it can be expected that boiling water markedly reduces the viable counts by several log units and also inactivates possible pathogens [4]. However, bacterial spores of the Bacillaceae family are resistant to thermal treatment usually applied in infusion preparation, and this thermal shock may stimulate spore germination. Some of these bacteria like B. cereus and C. perfringens are recognized as having potential pathogenicity and have been incriminated in food poisoning [12]. Thus, in extractions using only water, hot or cold, as extractor liquid, the stability of the extract becomes compromised and the risk of microbiological contamination increases significantly. This contamination can compromise the quality and integrity of the plant material itself, as well as products arising from its use [29-30].

In addition to extraction temperature, the choice of extraction solvent is another important factor to prevent microbial contamination. The aim of an extraction process should be, of course, to provide for the maximum yield of substances and of the highest quality (concentration of target compounds and pharmacological power of the extracts). For extraction of active phytochemicals, the most commonly used solvents are methanol, ethanol, hexane, chloroform and diethyl ether [31]. Herbal extraction which made by ethanol or methanol extraction should, in general, provide good hygiene conditions, but the result depends on the alcoholic concentration applied [4].

\section{3. $\mathrm{pH}$ influence}

The $\mathrm{pH}$ value is one of the main factors influencing the quality of medicine. It always controls many chemical and microbiological reactions [32]. When the $\mathrm{pH}$ value is low (presence of acidic substances), the bacterial count could be low, but at neutral or higher $\mathrm{pH}$ the level of contamination of the herbal preparations could observed to be higher. This suggests that a neutral or alkaline $\mathrm{pH}$ favoured high contamination levels of the herbal preparations. This agrees with the observation that bacterial growth is optimal at more or less neutral $\mathrm{pH}$, around pH 5-8.5 [1].

\subsection{Storage}

Most pre-storage processing of plant material, such as that involving drying, heat, cooling and packaging, can prevent the degradation of plant material during storage [33]. Storage of medicinal herbs is an important part in the process production. During storage, due the factors in the outside world and their own physical and chemical properties of the interaction, gradually occurring physical, chemical and biological changes. Prolonged storage in poorly 
ventilated storehouse usually increases sample moisture content in the bulk due to heat exchange capacity, rendering herbs more susceptible to molds growth and toxin production. Fungi are the predominant contaminants of herbs, but most such microbial populations are probably regarded as commensal residents on the plant that survived drying and storage. Most fungi are present on plants, which develop after harvest if relative humidity is not controlled during storage [34-35].

Moulds are responsible for biodeterioration of a number of substrates including raw materials of some medicinal plants. These moulds reduce raw herbal drugs shelf life and market value. The fungal deterioration adversely affects the chemical composition of the raw materials and thereby decreases the medicinal potency of herbal drugs [20]. Samples of herbal parts stored for sale in markets located in Ibadan, Nigeria were analysed for mycoflora associated with their storage and twenty eight fungal species were isolated, showing that herbal drug plant pieces are hazardous for human health [36]. Some samples of herbal raw materials have been reported to contain aflatoxin. The reference [37] determined the incidence of toxigenic fungi and their mycotoxins on 152 dried medicinal and aromatic herbs from Argentina, which are used as raw material for drugs. A. flavus and A. parasiticus were the predominant species isolated, and high aflatoxin concentrations were detected. There is a potential risk for mycotoxins contamination, especially during prolonged storage in poorly conditions without temperature and moisture control that usually render medicinal plants more susceptible to moulds growth and mycotoxins production $[5,10,20]$.

The reduction of plant enzyme activity and inactivation of microorganisms is achieved by drying. Dried plant materials tend to be hygroscopic (readily absorbing moisture) and must be stored under controlled humidity. Rehydration can lead to the decomposition of the bioactive metabolites by enzymes from microorganisms or the plant itself. Significant contamination by bacteria and fungi suggest inadequate storage facilities and poor hygienic practice during preparation of these medicinal plants. The storage processes of such products are stages during which it is important to avoid even further contamination [38].

Studies on long-term stability of dried herbal teas and preparations are rare. In a study of [20] was examined the deterioration of herbal drug samples which were stored for 6-9 months by traders after collection. Some of the contaminated materials were found to be deteriorated by toxigenic strains of A. flavus and contain aflatoxin B1 which was above the permissible limit. In a study of [38], dried $P$. lanceolata leaves were exposed to atmospheres of different relative humidity $(75,45$ and $0 \%$ ) for 24 weeks and was evaluated the chemical changes of the compounds of interest. It was shown that exposure to water results in loss of bioactive molecules of $P$. lanceolata dried leaves, and that colonising fungi are the key contributors to this loss. The fungal deterioration adversely affects the chemical composition of the raw materials and thereby decreases the medicinal potency of herbal drugs. Biodeterioration of herbal products samples by associated fungi during storage has drawn attention regarding quality maintenance of these products [35,38-40].

It is common practice for herbalists to prepare herbal medicines and store them in a refrigerator. However, in previous study the effect of microbial contaminants on active com- 
pounds of African plant extracts was assessed and indicated that after 25 days of storage in low temperature there may be little or no active compounds due to spontaneous biodegradation by naturally-occurring microbes [41]. The World Health Organization (WHO) recommends that whenever required and when possible, fresh medicinal plant materials should be stored at appropriate low temperatures, ideally at $2-8^{\circ} \mathrm{C}$; frozen products should be stored at less than $-20^{\circ} \mathrm{C}$.

Processed medicinal plant materials should be packaged as quickly as possible to prevent deterioration of the product and to protect against unnecessary exposure to potential pest attacks and other sources of contamination.

\section{Decontamination of plant materials}

Attempts have always been made to decontaminate and preserve these medicinal plants so as to get more safe, natural and potent medicines. The number of methods has been tried for decontamination such as heat treatment, UV irradiation and fumigation. However, volatility and heat sensitivity of the delicate flavor and aroma components of the medicinal plants do not permit the use of heat treatment [42].

Low penetration power of UV radiations makes this irradiation method unsuitable [42]. Fumigation with gaseous ethylene oxide brings down the microbial burden but this method is now prohibited or restricted in many countries due to the carcinogenic nature of one of its residue in treated medicinal plants $[43,44]$. Various disinfectant technologies have been suggested which include electromagnetic radiations, photodynamic pulsing, ultrahigh pressure and $\mathrm{CO}_{2}$ treatment [42].

Gamma irradiation is now getting recognition throughout the world as a phytosanitary treatment of herbal materials. It improves the hygienic quality of various herbal materials and reduces the losses due to microbial contamination and insect damage [45]. Besides, it is a fast, safe, convenient, eco-friendly method which reduces the reliance on chemical fumigants and preservatives currently used by industries. The chances of recontamination are also reduced, as it can be done after packaging [46]. Some studies showed that the exposition of plant samples to different doses of gamma radiation can result in reduction in total bacterial counts and also indicated that the microbial load could be decreased by increasing the radiation-absorbed dose. These studies indicate that gamma irradiation is an effective treatment for microbial decontamination of medicinal plants $[42,47,48]$.

Certain plants contain natural barriers and antimicrobial substances which exert typical inhibitory effects on microbial growth and stability. It has been estimated that around 1400 herbs and spices may possess antimicrobial agents of different chemical nature as oils, peptides, liquid and organic extracts [4]. Some medicinal herbs contain essential oils which act as natural antimicrobials and may inhibit mould development and mycotoxin production [11]. Different studies have demonstrated the effectiveness of antimicrobials and their effec- 
tive compounds to control or inhibit the growth of pathogenic and spoilage microorganisms [49-51].

\section{Microbial quality parameters}

The most widely accepted and used technique is that recommended by WHO for total count of microorganisms in plant materials. According to the methodology of the WHO, $10 \mathrm{~g}$ of sample should be suspended in $90 \mathrm{ml}$ of buffer sodium chloride-peptone, adjusting the $\mathrm{pH}$ to 7.0. To count total aerobic bacteria, sample should be plated in duplicate, using the official technique of sowing depth on casein-soybean digest agar, and then incubated at $30-35^{\circ} \mathrm{C}$ for 48h. To count yeast and mold, the technique employed is the sowing depth in Sabourauddextrose plus a solution of $10 \%$ tartaric acid to obtain $\mathrm{pH} 3.0$ to 3.5. The dilution is plated in duplicate and incubated at $20-25^{\circ} \mathrm{C}$ for 5 days [52]. Analysis of specific pathogens, Enterobacteriaceae and other Gram negative bacteria (E. coli, Salmonella sp., P. aeruginosa and S. aureus) consists of specific methods of cultivation and through biochemical and serological tests. The specification of $\mathrm{WHO}$ for total aerobic microorganisms is not more than $10^{7} \mathrm{CFU} / \mathrm{g}$ for the plant material for use as teas and infusions and at most $10^{5} \mathrm{CFU} / \mathrm{g}$ for internal use. The specification of WHO for yeasts and molds are at most $10^{4} \mathrm{CFU} / \mathrm{g}$ for the plant material for use as teas and infusions and at most $10^{3} \mathrm{UFC} / \mathrm{g}$ for internal use. High counts of fungi are a risk because of the possibility to produce mycotoxin, such as aflatoxin, which is a carcinogen toxin. The WHO also recommends a test to detect the possible presence of aflatoxins, which are highly dangerous contaminants in any material of plant origin.

In Brazil, despite the large consumption of products derived from plants, products sold and consumed were not subject to any kind of quality control. In 1995, the Ministry of Health instituted the ordinance MS/SNVS No. 6, January 31, 1995 [53] that regulated the registration of herbal products for commercial purposes. Then came the Resolution RDC No. 17 [54] and, more recently, the RDC No. 48 [55] which confirms definitely that are herbal medicines and thereby rescues the need for the existence of safety studies, efficacy and quality, prior to the registration of these products. The Resolution RDC No. 48 of March 16 of 2004 [55] recommends that the contamination analysis on herbal medicines must be in accordance with pharmacopoeial specifications.

Both the Brazilian Pharmacopeia [56], as the United States Pharmacopeia [57] draw the following specifications for products for oral use: 104 aerobic bacteria/g or $\mathrm{mL}, 10^{2}$ fungi/g and absence of Salmonella spp, E. coli and S. aureus. However, the Brazilian Pharmacopeia also indicates the detection of other indicators of increased risk for oral administration, such as $P$. aeruginosa, B. cereus, Enterobacter spp, C. albicans, A. flavus and A. parasiticus. High microbial loads are indicative of the possibility of potentially pathogenic microorganisms.

In Europe the evaluation of microbial contamination of medicinal plants has increasingly become an integral part of Good Agricultural Practice (GAP) and Hazard Analysis and Critical Control Point (HACCP) concepts [33]. The limits of microbial contamination given in European Pharmacopoeia [58] for herbal medicinal products to which boiling water is added before use are: total aerobic bacteria $\left(10^{7} \mathrm{CFU} / \mathrm{g}\right)$, fungi $\left(10^{5} \mathrm{CFU} / \mathrm{g}\right)$; for herbal medicinal products to which boiling water is not added before use are: total aerobic bacteria $\left(10^{5}\right.$ 
$\mathrm{CFU} / \mathrm{g})$, fungi (10 $\mathrm{CFU} / \mathrm{g})$; Enterobacteria and other Gram-negative organisms $\left(10^{3} \mathrm{CFU} / \mathrm{g}\right)$; E. coli and Salmonella sp. should be absent. In general, the tests used to verify the presence of microorganisms in plant drugs and microbial limits show no significant variation and follow the recommendations used for non-sterile pharmaceutical products (Table 1).

\begin{tabular}{|c|c|c|c|c|}
\hline & $\begin{array}{c}\text { United States } \\
\text { Pharmacopoeia }^{a}\end{array}$ & $\begin{array}{c}\text { European } \\
\text { Pharmacopoeia }^{b}\end{array}$ & WHOc & $\begin{array}{c}\text { Brazilian } \\
\text { Pharmacopoeia }^{d}\end{array}$ \\
\hline Aerobic bacteria & $10^{5} / 10^{4} / 10^{2}$ & $10^{7} / 10^{5}$ & $* / 10^{7} / 10^{5}$ & $10^{7} / 10^{5} / 10^{4}$ \\
\hline Mold and yeast & $10^{3} / 10^{2} / 10$ & $10^{5} / 10^{4}$ & $10^{5} / 10^{4} / 10^{3}$ & $10^{4} / 10^{3} / 10^{2}$ \\
\hline $\begin{array}{l}\text { Enterobacteria and } \\
\text { other Gram negative } \\
\text { bacteria }\end{array}$ & $10^{3} / * / *$ & $* / 10^{3}$ & $* / 10^{4} / 10^{3}$ & $10^{4} / 10^{3} / 10^{2}$ \\
\hline E. coli & absent & $10^{3} /$ absent & $10^{4} / 10^{2} / 10$ & absent \\
\hline Salmonella & absent & * / absent & * / absent /absent & absent \\
\hline \multicolumn{5}{|c|}{$\begin{array}{l}\text { a United States Pharmacopoeia: The first value represents dried or powdered botanicals and botanicals to be treated with } \\
\text { boiling water before use; The second value represents tinctures, powdered botanicals extracts, fluid extracts and nutritional } \\
\text { supplements with botanicals; The third value represents infusions/decoctions. }{ }^{b} \text { European Pharmacopoeia: Herbal medicinal } \\
\text { products consisting solely of one or more herbal drugs (whole, reduced or powdered): the first value represents herbal } \\
\text { medicinal products to which boiling water is added before use; The second value represents herbal medicinal products to } \\
\text { which boiling water is not added before use. ' WHO: The first value represents contamination of "crude" plant material } \\
\text { intended for further processing; The second value represents for plant materials that have been pretreated (e.g. with boiling } \\
\text { water as used for herbal teas and infusions) or that are used as topical dosage forms; The third value represents For other } \\
\text { plant materials for internal use: }{ }^{d} \text { Brazilian Pharmacopoeia: The first value represents herbal drugs to which boiling water is } \\
\text { added before use; The second value represents herbal drugs to which the extractive process made in cold temperature; The } \\
\text { third value represents final products for oral use. * Limits are not specified. }\end{array}$} \\
\hline
\end{tabular}

Table 1. Recommended microbial limits for herbal drugs (values in CFU/g).

\section{Conclusion}

Microbial contamination can lead to impaired performance of the product due to disruption of the stability of the formulation, modification of physical characteristics and appearance and lead to inactivation of the active ingredients and excipients in the formulation and also cause loss of confidence in the company. Herbalists should be trained to apply Good Manufacturing Practices, good harvesting practices and the safe handling and storage of herbal medicinal products. Further studies are recommended for herbal products to establish other contaminants and ways in which the contaminants can be reduced to recommended levels. The microbial loads should be established and the contaminants isolated and identified. In addition, alternative methods such as treatment with ethylene oxide or radiation with ionic rays lead to decontamination effects. These methods can be seen as a compromise between ensuring the microbiological safety of the product and avoiding consumer's risk and special 
legal permissions are required in many countries. It is evident that more detailed studies of plant species popularly used are needed in order to ensure the quality, an important concept for providing the wished security and reliability for its use.

\section{Author details}

Marcelo Gonzaga de Freitas Araújo* and Taís Maria Bauab

*Address all correspondence to: mgfaraujo@yahoo.com.br

Biological Sciences Department, Faculty of Pharmaceutical Sciences, São Paulo State University - UNESP, Araraquara, Brazil

\section{References}

[1] Abba, D., Inabo, H. I., Yakubu, S. E., \& Olonitola, O. S. (2009). Contamination of herbal medicinal products marketed in Kaduna Metropolis with selected pathogenic bacteria. African Journal of Traditional, Complementary and Alternative Medicines, 6, 70-77.

[2] Zhang, X. (1998). Regulatory situation of herbal medicines: a worldwide review. 2003: World Health Organization. Available at:, http://apps.who.int/ medicinedocs/en/d/Jwhozip57e/, (accessed 8 June 2012).

[3] Kunle, O. F., Egharevba, H. O., \& Ahmadu, P. O. (2012). Standardization of herbal medicines- A review. International Journal of Biodiversity and Conservation, 4, 101-112.

[4] Kneifel, W., Czech, E., \& Kopp, B. (2002). Microbial contamination of medicinal plants- A review. Planta Medica, 5-15, 68.

[5] Bugno, A., Almodovar, A. A. B., Pereira, T. C., Pinto, T. J. A., \& Sabino, M. (2006). Occurrence of toxigenic fungi in herbal drugs. Brazilian Journal of Microbiology, 37, 47-51.

[6] Busse, W. (2000). The significance of quality for efficacy and safety of herbal medicinal products. Drug Information Journal, 34, 15-23.

[7] Czech, E., Kneifel, W., \& Kopp, B. (2001). Microbiological status of commercially available medicinal herbal drugs- A screening study. Planta Medica, 67, 263-269.

[8] Tassaneeyakul, W., Razzazi-Fazeli, E., Porasuphatana, S., \& Bohm, J. (2004). Contamination of aflatoxins in herbal medicinal products in Thailand. Mycopathologia, 158, 239-244. 
[9] Okunlola, A., Adewoyin, B. A., \& Odeku, A. O. (2007). Evaluation of pharmaceutical and microbial qualities of some herbal medicinal products in South Western Nigeria. Tropical Journal of Pharmaceutical Research, 6, 661-670.

[10] Kulshrestha, R., Gupta, C. P., Shukla, G., Kundu, M. G., Bhatnagar, S. P., \& Katiyar, C. K. (2008). The effect of water activity and storage temperature on the growth of Aspergillus flavus in medicinal herbs. Planta Medica, 74, 1308-1315.

[11] Kosalec, I., Cvek, J., \& Tomic, S. (2009). Contaminants of medicinal herbs and herbal products. Archives of Industrial Hygiene and Toxicology, 60, 485-501.

[12] Kunene, N. F., Hastings, J. W., \& von Holy, A. (1999). Bacterial populations associated with a sorghum-based fermented weaning cereal. International Journal of Food Microbiology, 49, 75-83.

[13] Martins, H. M., Martins, M. L., Dias, M. I., \& Bernardo, F. (2001). Evaluation of microbiological quality of medicinal plants used in natural infusions. International Journal of Food Microbiology, 68, 149-153.

[14] Alwakeel, S. S. (2008). Microbial and heavy metals contamination of herbal medicines. Research Journal of Microbiology, 3(12), 683-691.

[15] Idu, M., Erhabor, J. O., \& Idele, S. O. (2011). Microbial load of some medicinal plants sold in local markets of Benin City, Nigeria. International Journal of Medicinal and Aromatic Plants, 1(3), 272-277.

[16] Halt, M. (1998). Moulds and mycotoxins in herb tea and medicinal plants. European Journal of Epidemiology, 14, 269-274.

[17] Amaike, S., \& Keller, N. P. (2011). Aspergillus flavus . Annual Review of Phytopathology, 49, 107-133.

[18] Bugno, A., Buzzo, A. A., Nakamura, C. T., Pereira, T. C., Matos, D., \& Pinto, T. J. A. (2005). Avaliação da contaminação microbiana em drogas vegetais. Revista Brasileira de Ciências Farmacêuticas, 41(4), 491-497.

[19] Anyanwu, C. U. (2010). Fungal contaminants of powdered herbal drugs sold in parts of Enugu State, Southeast, Nigeria. Plant Product Research Journal, 14, 46-50.

[20] Kumar, A., Shukla, R., Singh, P., \& Dubey, N. K. (2009). Biodeterioration of some herbal raw materials by storage fungi and aflatoxin and assessment of Cymbopogon flexuosus essential oil and its components as antifungal. International Biodeterioration $\mathcal{E}$ Biodegradation, 63, 712-716.

[21] Rocha, R. P., Melo, E. C., \& Radünz, L. L. (2011). Influence of drying process on the quality of medicinal plants: A review. Journal of Medicinal Plants Research, 5(33), 7076-7084.

[22] Müller, J., \& Heindl, A. (2006). Drying of medicinal plants. In: Bogers RJ, Craker LE, Lange D. (eds.), Medicinal and Aromatic Plants, Dordrecht: Springer, 237-252. 
[23] World Health Organization (WHO). (2003). WHO guidelines on good agricultural and collection practices [GACP] for medicinal plants. Geneva, World Health Organization.

[24] Oliveira, O. W., \& Petrovick, P. R. (2010). Secagem por aspersão (spray drying) de extratos vegetais: bases e aplicações. Revista Brasileira de Farmacognosia, 20, 641-650.

[25] Souza, T. P., Lionzo, M. I. Z., \& Petrovick, P. R. (2006). Avaliação da redução da carga microbiana de droga vegetal através do processamento tecnológico: decocção e secagem por aspersão. Revista Brasileira de Farmacognosia, 16, 94-98.

[26] Deans, S. G., Svoboda, K. P., \& Bartlett, M. C. (1991). Effect of microwave oven and warm-air drying on the microflora and volatile oil profile of culinary herbs. Journal of Essential Oil Research, 3, 341-347.

[27] Harbourne, N., Marete, E., Jacquier, J.C., \& O'Riordan, D. (2009). Effect of drying methods on the phenolic constituents of meadowsweet (Filipendula ulmaria) and willow (Salix alba). Food Science and Technology, 42, 1468-1473.

[28] Cowan, M. M. (1999). Plant products as antimicrobial agents. Clinical Microbiology Reviews, 12, 564-582.

[29] Migliato, K. F., Moreira, R. R. D., \& Mello, J. C. P. (2007). Sacramento LVS, Correa MA, Salgado HRN. Controle de qualidade do fruto de Syzygium cumini (L.) Skells. Revista Brasileira de Farmacognosia, 17, 94-101.

[30] Araújo, M. G. F., Galeane, M. C., Castro, A. D., Salgado, H. R. N., Almeida, A. E., Cunha, W. R., Veneziani, R. C. S., \& Moreira, R. R. D. (2010). Pharmacognostical evaluation of fruits of Solanum lycocarpum A. St.-Hill. (Solanaceae). Pharmacognosy Journal, 2(9), 248-253.

[31] Castillo, F., Hernández, D., Gallegos, G., Mendez, M., Rodríguez, R., Reyes, A., \& Aguilar, C. N. (2010). In vitro antifungal activity of plant extracts obtained with alternative organic solvents against Rhizoctonia solani Kühn. Industrial Crops and Products, 32, 324-328.

[32] Liu, X., Qiu, Z., Wang, L., \& Chen, Y. (2011). Quality evaluation of Panax notoginseng extract dried by different drying methods. Food and Bioproducts Processing, 89, 10-14.

[33] Fennel, C. W., Light, M. E., Sparg, S. G., Stafford, G. I., \& van Staden, J. (2004). Assessing African medicinal plants for efficacy and safety: agricultural and storage practices. Journal of Ethnopharmacology, 95, 113-121.

[34] Aziz, N. H., Youssef, Y. A., El -Fouly, M. Z., \& Moussa, L. A. (1998). Contamination of some common medicinal plant samples and spices by fungi and their mycotoxins. Botanical Bulletin of Academia Sinica, 39, 279-285.

[35] Mandeel, Q. A. (2005). Fungal contamination of some imported spices. Mycopathologia, 159, 291-298. 
[36] Efunyoye, M. O. (1996). Fungi associated with herbal drug plants during storage. Mycopathologia, 136, 115-118.

[37] Rizzo, I., Vedoya, G., Maurutto, S., Haidukowski, M., \& Varsavsky, E. (2004). Assessment of toxigenic fungi on Argentinean medicinal herbs. Microbiological Research, 159, 113-120.

[38] Gonda, S., Tóth, L., Gyémánt, G., Braun, M., Emrid, T., \& Vasas, G. (2012). Effect of high relative humidity on dried Plantago lanceolata L. leaves during long-term storage: Effects on chemical composition, colour and microbiological quality. Phytochemical Analysis, 23, 88-93.

[39] Singh, P., Srivastava, B., Kumar, A., \& Dubey, N. K. (2008). Fungal contamination of raw materials of some herbal drugs and recommendation of Cinnamomum camphora oil as herbal fungitoxicant. Microbial Ecology, 56, 555-560.

[40] Shukla, R., Kumar, A., Prasad, C. S., Srivastava, B., \& Dubey, N. K. (2008). Antimycotic and antiaflatoxigenic potency of Adenocalymma alliaceum Miers. on fungi causing biodeterioration of food commodities and raw herbal drugs. International Biodeterioration $\mathcal{E}$ Biodegradation, 62, 348-351.

[41] Du Plessis-Stoman, D., Downing, T. G., van de Venter, M., \& Govender, S. (2009). Traditional herbal medicines: potential degradation of sterols and sterolins by microbial contaminants. South African Journal of Science, 105, 147-150.

[42] Gupta, P. C., Garg, N., \& Joshi, P. (2011). Effect of gamma irradiation on the extraction yield and microbial contamination of medicinal plants. Internet Journal of Food Safety, 13, 351-354.

[43] Kim, M. J., Yook, H. S., \& Byun, M. W. (2000). Effects of gamma irradiation on microbial contamination and extraction yields of Korean medicinal herbs. [2]. Radiation Physics and Chemistry, 57, 55-58.

[44] Satomi, L. C., Soriani, R. R., \& Pinto, T. J. A. (2005). Descontaminação de drogas vegetais empregando irradiação gama e óxido de etileno: aspectos microbianos e químicos. Revista Brasileira de Ciências Farmacêuticas, 41(4), 445-450.

[45] Farkas, J. (1998). Irradiation as a method for decontaminating food: A review. International Journal of Food Microbiology, 44, 189-204.

[46] Khattak, K. F., Simpson, T. J., \& Ihasnullah, . (2009). Effect of gamma irradiation on the microbial load, nutrient composition and free radical scavenging activity of $\mathrm{Ne}$ lumbo nucifera rhizome. Radiation Physics and Chemistry, 78, 206-212.

[47] Khattak, K. F. (2012). Evaluation of microbial loads, physical characteristics, chemical constituents and biological properties of radiation processed Fagonia arabica. Radiation Physics and Chemistry, 81, 679-685. 
[48] Aquino, S., Gonçales, E., Rossi, M. H., Nogueira, J. H. C., Reis, T. A., \& Corrêa, B. (2010). Evaluation of fungal burden and aflatoxin presence in packed medicinal plants treated by gamma radiation. Journal of Food Protection, 73(5), 932-937.

[49] Tiwari, B. K., Valdramidi, V. P., O’Donnell, C. P., Muthukumarappan, K., Bourke, P., \& Cullen, P. J. (2009). Application of natural antimicrobials for food preservation. Journal of Agricultural and Food Chemistry, 57, 5987-6000.

[50] Wang, Y., Lu, Z., Wu, H., \& Lv, F. (2009). Study on the antibiotic activity of microcapsule curcumin against foodborne pathogens. International Journal of Food Microbiology, 30, 71-74.

[51] Negi, P. S. (2012). Plant extracts for the control of bacterial growth: Efficacy, stability and safety issues for food application. International Journal of Food Microbiology, 156, 7-17.

[52] World Health Organization (WHO). (1998). Quality control methods for medicinal plant materials. Geneva, World Health Organization.

[53] Brasil, Ministério da Saúde, Secretaria Nacional de Vigilância Sanitária. (1995). Portaria no 6., Diário Oficial da Repúplica Federativa do Brasil, 31 jan. Institui e normaliza o registro de produtos fitoterápicos.

[54] Brasil, Ministério da Saúde, Agência Nacional de Vigilância Sanitária. (2000). RDC no 17., Diário Oficial da República Federativa do Brasil, 24 abr. Aprova regulamento técnico, normatizando o registro de medicamentos fitoterápicos junto ao Sistema de Vigilância Sanitária.

[55] Brasil. Resolução RDC no 48. (2004). de 16 de março de 2004. Dispõe sobre o registro de medicamentos fitoterápicos. Diário Oficial [da] República Federativa do Brasil, Brasília, DF, 18 mar. 2004. Disponível em:, http://www.anvisa.gov.br/legis/resol/ 2004/48_04rdc.htm, Acesso em: 8 june 2012.

[56] Farmacopéia Brasileira. (1988). 4. ed. São Paulo: Atheneu, Parte 1. pV.5.1.6.-1- V. 5.1.7.-6.

[57] The United States Pharmacopeia. (2005). 28 ed. Rockville: United States Pharmacopeial Convention, 3013.

[58] European Pharmacopoeia. (2007). Microbiological quality of pharmaceutical preparations. Chapter 5.1.4, 6. ed. Strasbourg: EDQM., 4451. 
